OPTIMUM. STUDIA EKONOMICZNE NR 6 (66) 2013

\title{
RYNEK PRACY I POLITYKA SPOKECZNA W XXI WIEKU. ASPEKTY MAKROEKONOMICZNE I REGIONALNE
}

\author{
KONFERENCJA NAUKOWA \\ KOMITET NAUK O PRACY I POLITYCE SPOŁECZNEJ PAN \\ INSTYTUT PRACY I SPRAW SOCJALNYCH W WARSZAWIE \\ WYDZIAŁ EKONOMII I ZARZADZANIA UNIWERSYTETU W BIAŁYMSTOKU \\ SUPRAŚL, 21-23 MAJA 2013 R.
}

W dniach 21-23 maja 2013 r w Supraślu odbyła się konferencja naukowa pt.: Rynek pracy i polityka społeczna w XXI wieku. Aspekty makroekonomiczne i regionalne, zorganizowana przez Instytut Pracy i Spraw Socjalnych oraz Wydział Ekonomii i Zrządzania Uniwersytetu w Białymstoku. Zgromadziła ona przedstawicieli środowiska naukowego, uniwersyteckiego i instytutów wykonujących pracę badawczą o charakterze bardziej aplikacyjnym, m.in. z: Łodzi, Warszawy, Torunia, Poznania, Białegostoku, Gdańska.

Na konferencji dyskutowano o problematyce dynamiki rynku pracy, zwłaszcza w kontekście zmian demograficznych oraz instytucjonalnych, zmierzających w kierunku doskonalenia procesów zarządzania sprawami publicznymi. Zmiany te rodzą istotne wyzwania wobec kształtowania sytuacji na rynku pracy i w polityce społecznej. Spotkanie otworzyli: profesor Kazimierz W. Frieske, dyrektor Instytutu Pracy i Spraw Socjalnych, doktor Lucyna MacholZajda, sekretarz Komitetu Nauk o Pracy i Polityce Społecznej PAN oraz doktor Adam Wyszkowski, prodziekan WEiZ Uniwersytetu w Białymstoku. W pięciu sesjach wygłoszono ponad 30 referatów.

Sesję I rozpoczął referat profesora Kazimierza W. Frieske (IPiSS) pt.: Qui non laborat, non manducet. Czy rzeczywiście? Autor zaproponował bliższe przyjrzenie się tej, często przywoływanej, maksymie dotyczącej pracy, przede wszystkim dlatego, że sens tego stwierdzenia zmienia się $w$ zależności od tego, jak definiujemy pracę. Praca może być postrzegana jako towar, ale także jako nieodłączny element ludzkiego życia czy moralny obowiązek. Profesor odwołał się do pojęcia moral economy i economy of affection, których podstawowa myśl jest taka, że alokacja zasobów i wymiana może być organizowana niekoniecznie przez mechanizmy rynkowe, lecz przez normy moralne, ponieważ odnosi się do członków danej społeczności. Oba pojęcia wiążą się z dwiema ważnymi zasadami - kształtowania ładu społecznego dzięki podzielanym społecznie normom moralnym i pomyślności grupy, wspólnoty jako podstawowego układu odniesienia. Jednym z postulatów współczesnego społeczeństwa jest społeczna integracja, którą chcemy zapewnić przez pracę. Pomysł ten - jak wskazał referent sięga brytyjskiego ustawodawstwa Poor Law, choć współcześnie zmieniają się pojęcia lub inaczej są rozkładane akcenty. Pozostaje pytanie, co jest celem współczesnej integracji - traktowanie pracy jako moralnego obowiązku czy kontrola społeczna?

Profesor Jerzy Krzyszkowski (APS w Warszawie) przedstawił kierunki rozwoju pomocy społecznej po 1989 roku , wskazując główne zalety i ograniczenia dotychczasowych działań systemu pomocy społecznej. Poddał analizie: historyczny rys rozwoju systemu pomocy społecznej, rozwoju metod pracy socjalnej i krystalizowania się zawodu pracownika socjalnego. Zaprezentował również statystyczny obraz klientów pomocy społecznej - ośrodków pomocy społecznej i powiatowych centrów pomocy rodzinie i nakreślił podstawowe problemy systemu pomocy społecznej. Zostały scharakteryzowane główne wyzwania stojące przed reformato- 
rami systemu pomocy społecznej, tj.: problem pauperyzacji, starzenia się społeczeństwa oraz problemy obszarów wiejskich, z których coraz większy odsetek mieszkańców korzysta z pomocy społecznej. W konkluzjach prelegent unaocznił planowane reformy systemu, które mają w założeniu uczynić go bardziej efektywnym i skutecznym.

Z kolei, profesor Andrzej Bocian (UwB) omówił proces globalizacji z punktu widzenia popytu i podaży oraz dynamiki zmian demograficznych - starzenia się społeczeństwa. Globalizacja intensyfikuje przepływy różnego rodzaju kapitałów. Ukazując prognozy demograficzne dla różnych krajów, autor referatu zaznaczył, że procesy migracyjne to nie tylko popyt na pracę, ale także wyzwania kulturowe i organizacyjne.

Sesję I zamykało wystąpienie profesora Marka Bednarskiego (UW, IPiSS Socjalnych) poświęcone zagadnieniu szarej strefy i jej konsekwencjom dla rynku pracy i integracji społecznej. Jak opisał autor referatu, myśląc o konsekwencjach dla rynku pracy, należy mieć na uwadze to, że szara strefa kreuje miejsca pracy, ponieważ obniża jej koszty. Trudno policzyć, ile miejsc pracy utracono w gospodarce oficjalnej w wyniku powstania tych w szarej strefie. Zdaniem profesora Bednarskiego, należy ostrożnie podchodzić do, dość powszechnie wygłaszanej, tezy, że szara strefa generuje gorsze miejsca pracy. Trzeba bowiem wziąć pod uwagę to, że w ogóle daje ona pracę. Szara strefa bowiem może prowadzić do ekskluzji w trzech wymiarach: w roli pracownika (gorsze miejsce pracy, słabsza jakość pracy), przedsiębiorcy (wyraźnie określony pułap rozwoju firmy), konsumenta (produkt szarej strefy bywa gorszy i pozbawiony gwarancji). Przeniesienie miejsc pracy z szarej strefy do gospodarki oficjalnej może wymagać obniżenia standardów miejsc pracy lub obniżenia transferu do budżetu dla wybranych działań (np. nieopodatkowane miejsca pracy dla słabszych).

Sesja II była poświęcona: zasobom pracy, zarządzaniu kapitałem ludzkim oraz przemianom na rynkach pracy w okresie kryzysu. Otworzył ją referat profesora Eugeniusza Kwiatkowskiego (UŁ), który zaprezentował cząstkowe wyniki badań szerszego projektu badawczego, dotyczącego zmian na rynku pracy. Celem tych badań było określenie zmian na rynku pracy, mierzonych zatrudnieniem i poziomem bezrobocia, jak również próba objaśnienia przyczyn zróżnicowania wskaźników w tych dwóch wymiarach w poszczególnych krajach OECD. Wykorzystując dane statystyczne z lat 2006-2012, referent pokazał dynamikę zatrudnienia.

Analiza prowadziła do wskazania dwóch głównych hipotez. Pierwsza z nich głosi, iż jednym z powodów zróżnicowania spadków popytu na pracę w różnych krajach jest otwartość gospodarek krajowych. Im bardziej otwarta gospodarka krajowa, tym bardziej jest ona wrażliwa na zewnętrzne bodźce z konsekwencjami dla rynku pracy. Zmiany na rynku pracy w postaci spadku zatrudnienia czy wzrostu bezrobocia nie muszą zachodzić natychmiast i nie muszą być podstawowe. Mogą dotyczyć: spadku wysokości płacy realnej, czasu pracy, intensywności i produktywności pracy. Z tym jest związana druga z hipotez. Im większa elastyczność płac czy czasu pracy, tym mniejszy spadek zatrudnienia w czasie kryzysu. Autor odniósł się także do prawnej ochrony zatrudnienia, jako ważnego elementu dostosowania strategii rynku pracy do sytuacji wynikającej z kryzysu, bowiem stopień restrykcyjności prawnej ochrony zatrudnienia ma wpływ na sytuację na rynku pracy.

Kolejny referat - profesor Jolanty Grotowskiej-Leder i magister Blanki Serafin-Juszczak (UŁ) dotyczył niewykorzystania zasobów pracy w perspektywie UE. Posłużył analizie sytuacji osób zaliczanych do kategorii NEET - młodzieży, która nie pracuje, nie uczy się i nie dokształca się. W Polsce ta kategoria jest określana „Ani Ani”. W wystąpieniu przedstawiono charakterystykę zjawiska w krajach UE i Polsce, a także zróżnicowanie zjawiska w poszczególnych państwach oraz jego społeczne i ekonomiczne koszty. W analizach zostały wykorzystane dane Eurostatu i wnioski raportu z 2012 roku przygotowanego przez Europejską Fundację na Rzecz Poprawy Warunków Życia i Pracy.

Profesor Biruta Skrętowicz (UMSC) w referacie poświęconym aktywności ekonomicznej ludności Polski omówiła kwestie zatrudnienia w podziale na: płeć, wiek i wykształcenie w świetle Narodowego Spisu Powszechnego z 2011 roku. W analizie autorka posługiwała się liczbami bezwzględnymi, kreśląc obraz zjawiska, oraz wskaźnikami struktury. W konsekwencji 
braku publikacji zawierających pełne dane ze spisu, autorka zajęła się wybranymi zagadnieniami.

Skuteczność stosowania w okresie kryzysu elastycznych form pracy w postaci „pracy skróconej" zaprezentował profesor Tomasz Budnikowski (Instytut Zachodni w Poznaniu). Uzasadnieniem wprowadzania nowych form pracy było gwałtowne załamanie rynków pracy w większości państw OECD w latach 2008-2009, które skierowało zainteresowanie decydentów i pracodawców w stronę elastycznych form pracy, m.in. pracy skróconej. Taka forma pracy umożliwia - zdaniem autora - znaczne ograniczenie rozmiarów bezrobocia. Instrument ten, znany w niektórych krajach od dziesięcioleci, w innych zyskał na popularności w ostatnich latach. Jego stosowanie, w opinii referenta, ma wiele zalet tak dla pracodawcy, jak i pracownika. Dla pracodawcy oznacza rezygnację z konieczności pozbywania się wykwalifikowanych pracowników w okresie załamania gospodarczego. Dla pracobiorcy pozwala oddalić w określonym czasie lub zupełnie wyeliminować niebezpieczeństwo bezrobocia. Praca skrócona jest wykorzystywana przede wszystkim w przedsiębiorstwach przemysłowych.

Zarządzanie zasobami ludzkimi było przedmiotem wystąpienia profesora Jerzego Grabowieckigo (UwB), który zaprezentował cząstkowe wyniki badań projektu stypendialnego rządu Japonii. Przedmiotem wystąpienia były kwestie zarządzania zasobami ludzkimi w japońskich grupach kapitałowych keiretsu, określane jako konglomeraty ekonomiczne, które zdominowały gospodarkę Japonii po drugiej wojnie światowej. Autor przedstawił historyczny rys (działające prężnie w II połowie XIX wieku struktury rodzinne, rody kupieckie) i genezę powstania grup keiretsu. W dalszej części referatu wyjaśniono istotę keiretsu, ich rolę (finansowanie nowych gałęzi produkcji) w gospodarce i omówiono najważniejsze elementy japońskiego systemu zarządzania zasobami ludzkimi.

Sesję zamykał referat poświęcony rozwojowi kapitału ludzkiego w regionach Unii Europejskiej. Profesor Marek Proniewski (UwB) przedstawił zagadnienie rozwoju regionów peryferyjnych w Unii Europejskiej, związanego z nimi rozwoju kapitału ludzkiego oraz jego zróżnicowanie w różnych regionach Unii Europejskiej. Omówił dynamikę wybranych wskaźników (m.in.: bezrobocia, zatrudnienia, skolaryzacji, umieralności, poziom dochodów gospodarstw domowych, uchodźców).

Sesja III była poświęcona problematyce starzenia się społeczeństwa i rezultatów tego procesu w odniesieniu do rynku pracy. Koncepcję aktywnego starzenia się w realiach polskiej gospodarki przedstawiła profesor Bogusława Urbaniak (UŁ). Omówiła ideę syntetycznej miary aktywnego starzenia się - wskaźnik AAl, który umożliwia ocenę poziomu rozwoju aktywnego starzenia się w danym kraju. Na podstawie tego wskaźnika referentka przeanalizowała zjawisko aktywnego starzenia się społeczeństwa polskiego i jego gospodarcze konsekwencje. Szczególną uwagę zwróciła na aspekty zatrudnienia osób starszych. Jak referentka podkreśliła, pożądany wzrost zatrudnienia po 50. roku życia staje się probierzem skuteczności działań wobec osób starszych na rynku pracy.

Jakie wymiary życia społecznego i zawodowego powinna brać pod uwagę aktywizacyjna polityka społeczna wobec osób powyżej 50. roku życia omówił doktor Piotr Szukalski (UŁ). Referent przedstawił kierunki docelowej aktywnej polityki rynku pracy wobec osób powyżej 50. roku życia na przykładach działań podejmowanych w Polsce i innych krajach europejskich (wydłużenie wieku emerytalnego, rozwój usług opiekuńczych). Wskazane zostały trzy możliwe spojrzenia na politykę społeczną, której celem jest utrzymanie aktywności ludzi na rynku pracy: zachęcanie do pozostania na rynku pracy (poprzez: poprawianie stanu zdrowia, podnoszenie poziomu kwalifikacji, wprowadzanie finansowych i podatkowych zachęt), umożliwianie aktywności (przez odpowiednie uregulowania prawne kierowane do pracodawców, stosowanie rozwiązań podatkowych) i stosowanie działań represyjnych, wymuszających pozostanie na rynku pracy.

Tendencje i bariery aktywności zawodowej osób starszych były przedmiotem wystąpienia doktor Lucyny Machol-Zajdy (IPiSS), która ukazała zmiany: ilościowe, strukturalne, czasowe i przestrzenne w kontekście procesu starzenia się społeczeństwa. Wykorzystując dane Eurostatu i Barometru, przedstawiono tendencje na rynku pracy. Przywołane wyniki badań opinii 
publicznej wskazują, że bezpieczeństwo warunków pracy i dbanie o zdrowie (także w wymiarze psychospołecznym) są kluczowymi kwestiami wpływającymi na decyzje osób starszych o kontynuacji aktywności zawodowej. Konieczne jest zatem dostosowywanie warunków w miejscach pracy do psychofizycznej kondycji starszych pracowników.

Doktor Zofia Czepulis-Rutkowska (IPiSS) zaprezentowała koncepcję i historię pojawienia się instytucji emerytury obywatelskiej, uwzględniając ewolucję funkcji systemów emerytalnych. Referentka przedstawiła argumenty na rzecz emerytury obywatelskiej we współczesnych realiach, a także możliwości jej wprowadzenia. Głównym przedmiotem analizy było znaczenie emerytury obywatelskiej w kontekście polskiej polityki emerytalnej. Punktem odniesienia był przebieg debaty w Wielkiej Brytanii, która rozważa wprowadzenie omawianego rozwiązania. Również w polskiej debacie emerytalnej pojawiła się w ostatnich latach propozycja zamiany obecnie funkcjonującego systemu emerytalnego na system emerytury obywatelskiej. Według referentki, realizacja tej koncepcji byłaby trudna, jednak sam projekt zmiany i przytaczane na jej rzecz argumenty stwarzają ważny punkt odniesienia do oceny funkcjonowania polskiego systemu, jak również pokazują zachodzące na świecie zmiany w polityce emerytalnej. Jak wskazała doktor Zofia Czepulis-Rutkowska, emerytura obywatelska jest jedną z propozycji, które jeszcze w większym stopniu niż dotychczas ograniczają zaangażowanie państwa w politykę emerytalną.

Rozważania, podjęte w referacie doktor Justyny Przywojskiej (UŁ), koncentrowały się na zagadnieniu rozwoju lokalnego i ukazaniu konsekwencji zjawiska starzenia się społeczeństwa dla przebiegu i priorytetów rozwoju lokalnego. Autorka przyjęła założenie, że do istotnych uwarunkowań rozwoju zalicza się potencjał tkwiący w członkach społeczności lokalnych i w sposobie zorganizowania struktur wspólnot samorządowych. Postępujący proces starzenia się społeczności lokalnych wymaga uwzględnienia zasobów i potrzeb osób starszych w programowaniu lokalnych strategii rozwoju.

Problematyka starzenia się społeczeństwa była również przedmiotem wystąpienia doktor Zofii Szwedy-Lewandowskiej (UŁ). Autorka wskazywała na konieczność rozwoju rynku usług opiekuńczych jako sposobu przeciwdziałania przedwczesnemu wycofywaniu się z rynku pracy osób na przedpolu starości (45-64 lata). Rozwój rynku usług opiekuńczych jest postrzegany jako szansa na aktywizację zawodową osób w tym przedziale wiekowym. Wraz z procesem starzenia się ludności będzie wzrastać zapotrzebowanie na usługi opiekuńcze. Jest to tym bardziej istotne, że z punktu widzenia opieki nad osobami starszymi jest widoczny dynamicznie postępujący proces podwójnego starzenia się populacji, czyli wzrost odsetka osób w wieku 80 lat i więcej. Z drugiej strony, będzie maleć potencjał opiekuńczy rodziny, co oznacza mniejsze możliwości zaspokajania potrzeb opiekuńczych seniora przez członków rodziny.

Sesję V rozpoczął referat doktor Anity Szymańskiej (UG), którego analiza była skoncentrowana na hipotezie głoszącej, iż społeczeństwo musi dokonywać wyboru pomiędzy ograniczaniem nierówności dochodowych a efektywnością rynku pracy (niski poziom bezrobocia i wysoki poziom zatrudnienia). Hipoteza ta objaśniała uwarunkowania funkcjonowania rynków pracy w USA i w Europie w połowie lat dziewięćdziesiątych XX wieku. Wskazywano, że negatywne szoki gospodarcze skutkują w krajach europejskich wzrostem bezrobocia, natomiast w USA wzrostem rozpiętości płac. Odmienność reakcji na te zjawiska wynika ze zróżnicowania poziomu elastyczności rynku pracy, w tym przede wszystkim płac.

Jak argumentowała referentka, dotychczas prowadzone badania w większości wypadków nie potwierdzają jednak wspomnianej hipotezy. Zazwyczaj zwraca się uwagę na obserwowany wzrost zróżnicowania dochodów w większości społeczeństw. Jako przyczyny tego wzrostu podaje się takie zjawiska, jak: liberalizacja handlu międzynarodowego, postęp technologiczny promujący wysokie kwalifikacje oraz deregulacja rynku pracy.

W kolejnym referacie doktor Kamil Zawadzki (UMK w Toruniu) przeprowadził dynamiczną, strukturalną i porównawczą analizę zatrudnienia w wybranych zawodach kreatywnych w Unii Europejskiej w latach 2004-2009. Autor ukazał zagrożenia dla dalszego rozwoju zatrudnienia w kreatywnej ekonomii, a także sformułował rekomendacje dotyczące zakresu interwencji państwa, niezbędnej do pełnego wykorzystania potencjału zatrudnieniowego analizowanych sektorów w czasie wychodzenia z recesji. 
Przedmiotem wystąpienia doktora Sławomira Kalinowskiego (UP w Poznaniu) była charakterystyka aktywności ekonomicznej ludności wiejskiej o niepewnych dochodach oraz analiza tych czynników, które decydują o relatywnie gorszej sytuacji badanej grupy na rynku pracy. $\mathrm{Na}$ podstawie empirycznych obserwacji referent omówił czynniki odpowiedzialne za podejmowanie pracy w formie nietypowej (na czas określony, „na czarno”, zastępstwo itd.) oraz wiążące się z nią poczucie niepewności dochodów. Przedstawił również czynniki sprzyjające poszukiwaniu pracy innej niż dotychczasowej oraz bodźce wpływające na rezygnację z poszukiwania nowego zatrudnienia. W wystąpieniu podjęto także takie zagadnienia, jak: podejmowanie aktywnych działań poprawiających własną konkurencyjność respondentów względem innych uczestników rynku pracy, przyczyny rezygnacji z dokształcania i aktywnego poszukiwania pracy, a także konsekwencje pasywnych postaw czy przyczyny osłabiające skłonność jednostek do podejmowania własnej działalności gospodarczej.

Doktor inżynier Andrzej Skibiński (PCz) zaprezentował problematykę wyborów edukacyjnych i rynku pracy w odniesieniu do sytuacji demograficznej na przykładzie województwa śląskiego. Według niego, jednym z bardziej niepokojących zjawisk, charakteryzujących górnośląski rynek pracy, jest wzrastający odsetek ludzi młodych pozostających bez pracy. W coraz mniejszym stopniu zdobyte wykształcenie chroni tę grupę osób przed skutkami bezrobocia, gdyż istotną barierą jest brak doświadczenia zawodowego oraz niedostosowanie zdobytych kwalifikacji zawodowych do zapotrzebowania na rynku pracy.

Jak zaznaczył referent, wyższa niepewność zatrudnienia odzwierciedla się m.in. w skokowym wzroście umów o pracę na czas określony. Wzrost ten obejmuje szczególnie młodą część populacji. Praca na podstawie tej formy umowy jest coraz częstszym sposobem wejścia na rynek pracy, co determinuje decyzje dotyczące prokreacji - młodzi ludzie odraczają decyzję o założeniu rodziny do czasu uzyskania bardziej stabilnej pozycji na rynku pracy. Skutki bezrobocia w tej grupie populacji w perspektywie kilku najbliższych lat mogą okazać się szczególnie dotkliwie dla rozwoju społeczno-gospodarczego.

Doktor Dorota Kałuża-Kopias (UŁ) przedstawiła skalę zmian, dotyczącą liczby i struktury potencjalnych zasobów pracy w pięciu największych miastach w Polsce. Jak wskazują liczne analizy demograficzne, przywołane przez referentkę, w perspektywie najbliższych dwudziestu lat rola czynnika demograficznego w kształtowaniu potencjalnych zasobów pracy zmieni się zasadniczo poprzez zmniejszenie się liczby osób w wieku produkcyjnym. Innym aspektem zmian demograficznych będzie proces starzenia się zasobów pracy. Egzemplifikacją analiz były dane z projekcji ludnościowej GUS, opublikowane w 2011 roku, prognoza dla powiatów i miast na prawach powiatów oraz podregionów.

Celem referatu doktor Moniki Wojdyło-Preisner (UŁ) była identyfikacja czynników determinujących długotrwałe bezrobocie w powiatach o nowoczesnej strukturze gospodarki na przykładzie miasta Białystok. Analizę przeprowadzono na podstawie danych pochodzących z systemu informatycznego Publicznych Służb Zatrudnienia Syriusz ${ }^{\text {STD }}$. Wykorzystując modele logitowe, prelegentka próbowała odpowiedzieć na pytanie o to, jaki wpływ na ryzyko długotrwałego pozostawania bez pracy wywierają: cechy społeczno-demograficzne bezrobotnych, ich uwarunkowania rodzinne, cechy obrazujące jakość kapitału ludzkiego, a także elastyczność w zakresie podejmowania pracy.

W obszarze analiz regionalnych pozostawało również wystąpienie profesora Józefa Rogowskiego i doktor Beaty Madras-Kobus (oboje z UwB). Autorzy dokonali przeglądu różnych metodologii obliczania stóp bezrobocia, stosowanych przez Główny Urząd Statystyczny w Polsce oraz przedstawili propozycję ich modyfikacji. Następnie obliczyli stopy bezrobocia według zaproponowanej metodologii w województwie podlaskim oraz omówili otrzymane wyniki.

O możliwościach wykorzystania dziedzictwa kulturowego i ich wpływie na rozwój regionu mówiła doktor Ewa Kasperska (PK). Wśród sposobów działania referentka wskazała inicjatywy lokalnych władz aktywizujące mieszkańców do angażowania się w przedsięwzięcia bazujące na lokalnych walorach i oddolne aktywności mieszkańców, którzy swój pomysł na życie chcą realizować, szukając inspiracji w dziedzictwie kulturowym regionu. W prezentacji posłużono się przykładami wykorzystania spuścizny dziedzictwa kulturowego z różnych stron Polski. 
Sesję zamykał referat magister Edyty Dąbrowskiej (UwB), którego przedmiotem była struktura popytu na pracę w województwie podlaskim w kontekście uwarunkowań struktury sektorowej gospodarki regionu. Prelegentka przeprowadziła analizę trójsektorowej struktury pracujących w województwie podlaskim, odnosząc wyniki analizy do struktury zatrudnienia według sektorów w skali kraju i wskazując na istotne różnice w tym obszarze. Różnice te, jej zdaniem, widoczne są zwłaszcza w podaży na pracę. W skali regionalnej częściej poszukuje się pracowników o niższych kwalifikacjach, niż pracowników posiadających kwalifikacje wysokospecjalistyczne.

Ostatnia $\mathrm{V}$ sesja była poświęcona problematyce godzenia ról zawodowych i rodzinnych oraz implementacji modelu flexicurity. Na podstawie analizy wyników badań empirycznych doktor Dorota Głogosz (IPiSS) oceniła wpływ wybranych czynników na kształtowanie się postaw polskich pracodawców wobec tzw. zatrudnienia przyjaznego rodzinie. Autorka omówiła szczegółowo, w jaki sposób czynniki, takie jak: sytuacja ekonomiczna, podaż pracy, normy prawne, wielkość firmy, wiedza i doświadczenie dotyczące łączenia pracy z życiem rodzinnym, determinują oceny i zachowania pracodawców.

Pozostając w kręgu tej tematyki, magister Agnieszka Smoder (IPiSS) na podstawie wyników badań empirycznych przedstawiła problematykę tworzenia przez pracodawców warunków, które sprzyjają łączeniu pracy z zobowiązaniami rodzinnymi. Referentka odniosła się do takich zagadnień, jak: rozumienie pojęcia zatrudnienia przyjaznego rodzinie, rodzaje stosowanych udogodnień dobrowolnych oraz ocena skutków ich wprowadzania. Jak wskazuje literatura przedmiotu, rozwiązania z zakresu zatrudnienia przyjaznego rodzinie, oferowane przez pracodawców, mają niwelować konflikt między pracą zawodową a życiem rodzinnym. Obejmuje to zarówno uprawnienia pracownicze, regulowane zapisami kodeksu pracy, jak i dodatkowe udogodnienia dla pracowników, wprowadzane dobrowolnie przez pracodawcę.

Następnie magister Joanna Mirosław (IPiSS) przeanalizowała sposób, w jaki doświadczenie prowadzenia własnej firmy sprzyja wdrażaniu w firmie rozwiązań przyjaznych rodzinie (uelastycznienie czasu pracy, wprowadzenie telepracy, zrozumienie rodzinnych problemów pracowników). Analizy opierały się na wynikach badań empirycznych, dotyczących aktywności kobiet i zatrudnienia przyjaznego rodzinie. Jak wskazywała referentka, faza rozwoju firmy, branża, sytuacja w rodzinie wpływają na możliwości godzenia ról zawodowych i rodzinnych. Jak pokazały badania, decyzja założenia własnej firmy wynika często z chęci ułatwienia sobie życia czy dążenia do pogodzenia obu ról zawodowych i rodzinnych.

Celem referatu doktor Małgorzaty Podogrodzkiej (SGH) był opis przestrzennego zróżnicowania płodności kobiet w wieku 25-34 lata w Polsce w latach 1991-2011 oraz ukazanie wzajemnych powiązań między tym zjawiskiem a natężeniem starzenia się ludności. Analizy prowadzono dla każdego województwa. W referacie postawiono kilka hipotez badawczych, dotyczących: przestrzennych różnic w natężeniu płodności, miejsc o wysokim wskaźniku urodzeń, związku wskaźników demograficznych ze wskaźnikiem płodności.

Omówienie definicji, założeń modelu flexicurity oraz wskazanie przykładów innych krajów i ich ścieżek implementacji modelu były przedmiotem referatu doktor Izabeli Łucjan (UMCS). Jak argumentowała prelegentka, zagadnienie to wymaga pogłębionych analiz z uwagi na to, że coraz częściej wskazuje się na konieczność opracowania i wdrożenia zintegrowanej strategii równoczesnego zwiększania elastyczności i bezpieczeństwa rynku pracy przez cały okres aktywności zawodowej człowieka.

W ostatnim referacie doktor Ewa Rollnik-Sadowska (PB) przedstawiła uwarunkowania duńskiego państwa dobrobytu, które stanowiły źródło tworzenia polityki flexicurity pod koniec XX wieku. Zaprezentowała rys historyczny kształtowania się państwa opiekuńczego w Danii oraz współcześnie obowiązujące zasady jego funkcjonowania. Prezentacja została opracowana na podstawie analizy literatury przedmiotu oraz wyników badań jakościowych, zrealizowanych w 2012 roku w Aarhus w Danii.

Zamykając to spotkanie, doktor Cecylia Sadowska-Snarska (UwB), organizatorka konferencji, podziękowała wszystkich referentom za przygotowane wystąpienia i uczestnikom za podjętą, żywą dyskusję. 